\title{
CROSSING BORDERS WITH TECHNOLOGY: USING GRAPHIC NOVELS IN FOREIGN LANGUAGE TEACHING
}

\author{
N. Berrin Aksoy
}

\begin{abstract}
Graphic novels and comics came into being in the 1930's as products of the popular culture that developed at an unprecedented pace especially after World War II. This paper explores the role of graphic novels and comics as an alternative to traditional means of language teaching in overcoming cultural and linguistic barriers that exist for the foreign language students at elementary, intermediate and higherlevels. It is argued that since graphic novels and comics are a combination of visual and narrative forms of artistic expression, these forms of literary and cultural production offer themselves as useful tools in the field of language education.
\end{abstract}

Key words: graphic novel; comics; popular culture; foreign language teaching

\section{Introduction}

Men of letters and artists express their creativity in more than one way. The innovations in the fields of technology, communication and in the audio - visual material have influenced and changed all aspects of our lives permanently. The developments in the modern world have paved the way towards using innovative material and methods in the sphere of education.

This paper aims to discuss the role of graphic novels and cartoons (comics) in the teaching of foreign languages and especially in the development of reading and writing skills of the students. Their role in bridging the gaps between mother tongue and foreign language will be presented by making references to research carried out in this field.

\section{Theoretical Framework}

Graphic novels as we understand them today came into being in the 1930's and Will Eisner is considered the father of the genre when he published his graphic novel A Contract with God in 1978. The book was the first of its kind, a graphic novel; enjoying all the advantages of cutting- edge technological tools and mass production of the paperback. The book is a collection of stories about the Jewish community in Bronx, New York. It's reception especially by young adults was

\footnotetext{
* Professor PhD at Atılım University, Translation and Interpretation Department, Ankara, Turkey, e-mail: berrin.aksoy@atilim.edu.tr
} 
very positive, even ground-breaking as a new genre and medium of a narrative form merged with visual representations depicting the dire conditions the Jewish community was living in. The book was very innovative in its technique which made use of both the narrative form and visual representations to back it up and realistically represent the message behind the narration. Hence, this was a beginning of a new genre which was named graphic novel, with a visual dimension which was not present in the traditional novels, until then.

Graphic novels have the ability to create a visual as well as a sequential narrative medium which combines text and image. As Will Eisner writes in Comics and Sequential Art (1985):

The future of this form awaits its participants who truly believe that the application of sequential art, with its interweaving of words and pictures, could provide a dimension of communication that contributes hopefully on a level never before attained to the body of literature that concerns itself with the examination of human experience. (Eisner 1985: 141-142, qtd. in Connors 2010: 67-68)

Human experience is a dominant and required feature of the realistic novel as described by Ian Watt in his book The Rise of the Novel (1960). In the above quotation, we see that Eisner's definition of the graphic novel essentially comprises the single quality of a genre to be accepted as a novel.

In The Chicago School of Media Theory, the writer writes that the word Novel implies the originality in narration; he goes on to say that the rise of the graphic novel in the latter half of the 20th century and the next corresponds to an increase in demand for fresh approaches in the communication of individual experience.

Time sequence and space are important elements of graphic novels. Their sequential quality drawn in panels and gutters is a unique quality belonging only to this genre. The layout of the page with the panels representing now, before, and after in visual as well as in narrative format enables the reader to perceive time in all its dimensions. Gutters, the space between the panels, are the pauses that give time and space to the reader to move freely to and from. Scott Mc Cloud, in Understanding Comics: the Invisible Art (1993), defines the graphic novel as juxtaposed pictorial and other images in deliberate sequence, intended to convey information and / or to produce an aesthete response in the viewer (1993: 9).

In a graphic novel, the viewer and the reader is capable, at once, to see the events at that particular time in its entirety on a single page of strip, simultaneous while reading and viewing. In that respect, it is like a scene in a movie, except that in a movie, the three dimensional time prception is impossible on a single scene. 
Mc Cloud goes on to say in defence of graphic art that:

The past is more than just memories for the audience and the future is more than just possibilities Both past and future are real and visible all around us Whereever your eyes are focused, that's now. But at the same time your eyes take in the surrounding landscape of past and future! In learning to read comics we all learned to percieve time spatially for in the world of comics time and space are one and the same. (Mc Cloud 1993: 104, fig.4, 5, 6)

Availability of moving through time by means of panels is one of the innovative qualities of the graphic novel thanks to the favorable conditions in terms of drawing materials, publication and printing of the images on cheap paper. Another important technical quality of the graphic novel is its absence of a continuous action in its panels, instead of which it offers a fraction of continuous action and hence requires the participation and involvement of the reader to fill in the non - existing pieces of the action. McLuhan (2017) writes that the exclusivity of depiction in the comic book affects the method of its consumption; the modern comic strip and comic book provide very little data about any particular moment in time, or aspect in space, of an object. The viewer, or reader, is compelled to participate in completing and interpreting the few hints provided by the bounding lines (McLuhan 2017: 1).

As mentioned earlier in this paper graphic novels contain text and picture or images at the same time. The simultaneity of this experience is an important quality; though in some instances only a single word or exclamation is used to accompany the pictures in the panels. In both forms, the reader must be actively involved to perceive the page in its simultaneity. This involvement as compared to reading a novel or watching a film is more toilsome since there are the gaps to be guessed and filled by the reader. Hence, the meaning of the story is created through the simultaneous interaction of seeing and reading and reading becomes synonymous with living in the imaginary mode of existence (Ricoeur 2017: 1).

\section{The Graphic Novel as a Literary Genre:}

It has been widely accepted that comics and graphic novels have become products of popular culture since mid 20th century in Europe and America. Despite this, popular academic and scholarly attention did not come as early as that. Critics and academics have put a distance between serious art and graphic novels and abstained from including them in the realm of literature and artistic creation. As a matter of fact the recent interest in the nature, originality and function of the graphic novel is still diverse and arguable. According to Baetens, more and more the debates around the graphic novels concern its literary qualities (2008: 77). Many graphic novels have a literary subtext or present themselves 
as the visual development of a literary text in the form of adaptations that is reproduced as a graphic novel for a variety of purposes. Beatens goes on to say that there are many examples of works of literature adapted into graphic novels such as Dino Battaglia's Maupassant, Alberto Breccia's Poe and Lovercraft, many of Dickens adoptations. In all these examples, these novels or stories are laid out on the pages in panels and speech balloons, or captions and the text and image juxtaposition creates a new literary model which is depicted in graphic interpretation (Baetens 2008: 78). Of course the literary merit or quality of the graphic novel is not only discussed within the boundaries of literary adaptations or appropriations of works of literature. Whether the graphic novel by itself is a literary genre or not is under scrutiny by the academics, critics and scholars, as well. Is it a new form of literature? If so why and how?

In order to address the above question, the qualities of graphic novel has to be identified. Most importantly, unlike the traditional novel, the literariness of a graphic novel depends on how the images are created. The graphic novel challenges the notion that literary narrative should always be created by means of a text and the textual characteristics. For graphic novels depend heavily on the image and how the text- bound elements are interpreted by the artist in terms of pictures and images. In this sense, the writer and the artist work in collaboration or singly, and have a larger space at his/their disposal. The text and the picture are complementary and have the potential to result in and create literary value like a book or a poem. Just like the reader of a novel or a poem the reader of the graphic novel makes sense of the story by means of the text and all the visual metaphors and images alike; that is by being actively involved in what is simultaneously there on the page. Another important issue about the literariness of the graphic novels is that the graphic novel evolved from comics in the fifties and under the same cultural and social conditions that led to the creation of news types of fiction such as post-modernist and experimental fiction.

Actually, the place of comics in American culture has long been recognized. According to Paolo Simonetti (2009), since the fifties, comics have played an important role in the American cultural landscape and have constituted an intertextual web of discourses and languages that include cinema, photography, painting and literature, constantly reinterpreting, institutionalizing, and reinventing former cultural experiences (2009: 379). He goes on to say that postmodernist fiction developed from comics by re-adopting narrative structures and textual strategies typical of comic boks and especially in the nineties, the techniques adopted by postmodernist fiction contributed to the evolution of comics into the graphic novel form. Simonetti (2009) states that by presenting comics in expensive book-format editions and by calling them novels instead of comic books, graphic novels now place themselves among avant-garde literature and perceived by readers as such (2009: 379). Simonetti, similar to Connors (2010), Baetens (2008), Eisner $(1985,1996)$, Round (2006) and many 
other academics, critics and artists, wraps up the arguments around the literary value of the graphic novel by putting forward that: "Nowadays, graphic novels are a solid reality in the literary panaroma, covering a broad range of topics and formats, from autobiography to science fiction, from history to literary classics, and it is high time we consider this medium as a serious and effective way of representing contemporary America" (2009: 354).

Comics, the earliest examples of the graphic novel, began around 1930's when comic strips in newspapers and journals developed into comics or comic books in the form of light satiric picture stories to be consumed in mass media productions. The Turkish researcher Levent Cantek explains the development of comics and the graphic novels in relation to their emergence as popular culture as such:

...the upper classes needed such tools (referring to the pictures on the walls of the churches) to control the people. Because, as opposed to the elitist world view of the upper classes, these tools are closer to the language of people and are more popular constructions. They constitute a synthesis between upper culture and folk culture by means of their form, structure, and content. This synthesis develops its own margins throughout the 19th century. Cultural massification (or mass culture) created by the industrial revolution, will initiate the age of this brand new popular culture. (translation mine, Cantek 2012: 18)

The development of comics into comic strips and comic books parallelled with the development of mass culture or popular culture tools and devices. Publishers of newspapers, magazines and journals were quick to notice the attraction and availability of mass consumption of these strips and books among the middle and lower-middle classes who could afford only a little time and limited means to have an access to reading and cultural materials of the higher classes. Hence, in order to increase the appeal of reading material to the public, publishers turned to the comics as an instrument to promote reading and literacy and hence education in general. Their contributions to building collections of visual texts and their ingenious aiming of the comic toward non-readers were the beginning spark toward a new view on literacy issues (Phelps 2011). Phelps goes on to say that the narratives of the comic books consisted of tales of modern life. These narratives were in response to a world in turmoil in the wake of the world wars. People were looking for a way to escape from their everyday lives and comics offered that kind of an escape. Comic books originally consisted of tales of superheroes and adventurers who were reaching to world issues, but they were also directed toward a juvenile audience (Phelps 2011: 21).

The transition from comics, into comic books and eventually to the graphic novels brought about a variety of content matter and formal innovations thanks to the new technologies in visual art and printing fields. Today's graphic 
novels contain a wide spectrum of topics ranging from fantastic stories to real world issues such as politics, ideology, gender, cultural issues, humour, and to adaptations of literature. Formwise, the graphic novels employ all the elements of literary style such as metaphors, personifications, imagery, allusions and the like. The text and the picture in a graphic novel are multi-layered and can convey meaning either explicitly or intricately.

\section{The Use of the Graphic Novel for Overcoming the Barriers in Lan- guage Teaching}

Comics and comic books can be used pedagogically on all the levels of education. However, due to its length and complexity of subject-matter, the graphic novel may as well be used as a foreign language teaching material in the intermediate or higher- level learners such as those in higher education.

The merits of using literature in the classroom of advanced language learners have been discussed by and large in the academia so far; however, current arguments for the use of graphic novels along with traditional novels have been heated with the emergence of the graphic novel as a literary genre. There have been educators and academics who claimed that comic books and graphic novels have become an obstacle for the students on the way to improving their literature reading, or foreign language skills, focusing on the "lack of aesthetic and artistic value" of such books. Sean P. Connors writes that in 1940 a literary critic for the Chicago Daily News, named Sterling North, was one of the first person to question the propriety of allowing adolescents to read comic books and argued that it was necessary to ensure that young readers had recourse to quality literature (Connors 2010: 66 ).

Arguments as above dwindled with the end of World War II and with the advent of the popular culture the graphic novel became an appropriated instrument to be used in order to ignite the interest of students in reading literature either in their mother-tongue or in foreign language and narrations of various types and kinds such as philosophical, social and scientific. According to Phelps (2011), through the use of graphic novels, while students are learning the traditional methods of studying the written word, they are also adopting new skills through the images (2011: 22). In her thesis, she refers to Rocco Versaci who remarks that students can develop this new skill with graphic text because [u]nlike more "traditional literature" [graphic texts] are able to quite literally "put a human face" on a given subject... a [graphic text] does not "happen in the words, or the pictures, but somewhere in-between, in what is sometimes known as the marriage of text and image" (2011: 22).

Turkish academics Hüseyin Öz and Emine Efecioğlu (2015) produced an article which comprises their collaborative report on the findings of a study which 
investigated the role of graphic novels in teaching English as a foreign language to highschool students in a Turkey. According to the findings of the study, the authorts assert that learners can greatly benefit from the graphic novel especially in reading classes to improve their reading skills. Öz and Efecioğlu refer to Goldsmith (2005) when they put forward that graphic novels are read for fun and that it may be a good idea to provide a teenager with something that appeals to him/her more than a long narrative since comics and visual material draw their attention more in our age (2015: 77).

Öz and Efecioğlu (2015) underline another important aspect of using graphic novel in language learning by putting forward that graphic novel can serve as a means for presenting sociocultural issues in language learning (2015: 77). Öz and Efecioğlu give The Four Immigrants Manga (Kiyama 1999) as an example to exposing language learners to the life of four Japanese immigrants in the USA (2015: 77). Likewise, Maus (Spiegelman 1973) can be another example for introducing the elementary, intermediate or higher-level language learners to the devastations of wars and to the struggles of the Jewish people during WWII. Graphic novels as such enhance the language learner's cultural and social awareness in a form and presentation which will draw their attention more easily as opposed to traditional written material. In this context, Öz and Efecioğlu (2015) set out to fill the empirical research gap in the field of the role of graphic novels in foreign language teaching in Turkey, starting from the premise that graphic novels have the potential to promote teaching and learning English as a foreign language. Hence, their study "aims to investigate the role of graphic novels in FLT" (Öz and Efecioğlu 2015: 80). In the study, several research questions were formulated and the method of study was mixed-methods research design which combined both quantitative and qualitative research (Öz, Efecioğlu 2015: 75-90).

According to the findings of the above- mentioned study, it was:

...revealed that there was a significant difference of achievement in reading graphic novels between the control and experimental group. Another interesting finding was that although it was found that graphic novels had a positive role in learning the target language in general, it was also seen that they play an important role in shaping one's language. The results further revealed that the students showed more success in the interpretation of the literary devices and techniques. The students that used the graphic novel could easily recognize the foreshadowing, symbolic language, comment on the setting and infer deeper meaning. (Öz, Efecioğlu 2015: 87)

Within the context of elementary and intermediate levels of teaching Turkish as a foreign language to Erasmus students in a Turkish University, a study was conducted by Celile Eren Ökten and Marie Helene Sauner in 2005-2007 academic years (Ökten, Sauner 2015: 65-79). According to the findings of this 
study it was observed that pictured texts, graphic novels, comics, ads and similar materials proved to be more efeective as compared to the traditional written material in the development of reading and writing skills of the foreign students who were learning Turkish. Ökten and Sauner (2015) concluded that illustrated texts contribute to a more active and careful grammar acquisition connected with daily life and oriented towards problem-solving. Adopting illustrated texts such as comics, caricatures, ads, jokes, etc. as authentic material is more efficient in improving grammar, reading and writing skills of foreign students at elementary and intermediate levels in terms of time spent and outcomes reached (Ökten, Sauner 2015: 65).

Developing new skills through the pictures and through all visual metaphors and images may be the key issue for the elementary, intermediate and higherlevel foreign language learners in overcoming the barriers put down by only the written text and the confinement of the written text that bounds the reader only to the written words on the page. Contrary to this experience, which is undeniably wholesome for many, the page of the graphic book offers multilayered experience to the reader to produce meanings and to make connections with the foreign elements, be them linguistic, cultural, or artistic, taking into consideration that improving foreign language teaching and learning can benefit from multiple modes and situations.

Consequently, the following characteristics of graphic novels may be regarded as beneficial on all levels of foreign language teaching:

-Graphic novels tell a complex or simple story by way of the juxtaposition of the text and the picture;

-The language used in the graphic novel has to be carefully chosen and related to daily language to fill in the captions and speech balloons;

-The graphic novel is oriented towards daily life and cultural varieties;

-The content of the graphic novel can have the power to have an immediate effect on the reader since it can have a striking format and page layout; hence, the message can be internalized at a deeper level by the reader;

-The graphic novel can provide the reader with social, economic conditions of the culture in which they are produced and with current trends, customs, and realia of the foreign culture by means of the pictures and images;

-The graphic novel, by means of the drawings of facial expressions accompanied by the speech balloons or captions can communicate the frames of minds and ways of thinking and behaving in certain situations of the characters of a foreign culture. 


\section{Conclusion}

It may be a good idea to make a reference to an opinion put forward in 1946 which paved the way for the employment of the graphic novels, comic books of an earlier period, and which prepared the background and foundation of its use as a tool in overcoming some of the challenges of foreign language learning:

The teaching of English today is far more complex matter than it was thirty or forty years ago. It is not that the essential character of the adolescent student changed or that the principles of grammar or the tenets that govern good literature have been modified, but rather that the average student of the present is being molded in many ways by three potent influences: the movies, the radio, and the comic book. (qtd. in Connors 2010: 66)

Taking into consideration the impact of the even more various influences to which the young students of the 21st century are exposed, the above remark acquires a new significance and relevance in terms of its recognition and acknowledgment of the need for new ways of coping with the complexities of teaching a foreign language. The graphic novel, with its accessibility and ability to lend itself to a variety of uses that the creative and imaginative teacher of a foreign language is free to devise, offers itself as an excellent tool in our efforts to meet this challenge in foreign language teaching.

\section{References:}

Baetens 2008: Baetens J. Graphic Novels: Literature Without Text?. - English Language Notes. 46: 2 Fall/ Winter. 77-88.

Cantek 2012: Cantek L. Türkiye'de Çizgi Roman. İletişim.

Connors 2010: Connors S. P. The Best of Both Worlds. - The Alan Review. Summer. 6568.

Eisner 1978: Eisner W. A Contract with God. New York: Baronet Books

Eisner 1985: Eisner W. Comics and Sequential Art. Tamarac, Florida: Poorhouse Press.

Eisner 1996: Eisner W. Narrative and Graphic Storytelling. New York: Poorhouse Press.

McCloud 1993: McCloud S. Understanding Comics: the Invisible Art. New York: Harper Perennial.

McLuhan 2017: McLuhan M. in Graphic Novel. The Chicago School of Media Theory. 1-7. $<$ https://lucian.uchicago.edu/blogs/mediatheory/keywords/graphic-novel $>$ [Accessed 17 Jan. 2014].

Öz, Efecioğlu 2015: Öz H., E. Efecioğlu. Graphic Novels: An Alternative Approach to Teach English as a Foreign Language. - Journal of Language and Linguistic Studies. 11(1), 75-90.

Ökten, Sauner 2015: Ökten C., M. H. Sauner. Yabancı Dil Olarak Türkçe Öğretiminde Resimli Metin Okumaları. - Hacettepe Üniversitesi Yabancı Dil Olarak Türkçe Araştırmaları Dergisi. Kış(2). 65-79. 
Phelps 2011: Pedagogy of Graphic Novels. Masters Theses and Specialist Projects. Paper 1065. <http://digitalcommons.wku.edu/theses/1065> [Accessed 12 Jan. 2017].

Ricoeur: Ricoeur P. in Graphic Novel. The Chicago School of Media Theory. 1-7. $<$ https:// lucian.uchicago.edu/blogs/mediatheory/keywords/graphic-novel $>$ _[Accessed 15 Jan. 2017].

Round 2006: Round J. From Comic Book to Graphic Novel: Writing, Reading, Semiotics. PhD Dissertation. University of Bristol, United Kingdom. <https://research-information. bristol.ac.uk/en/theses/from-comic-book-to-graphic-novel--writing-readingsemiotics(749e82e7-e402-4129-9827-89588e2a8c10).html.> [Accessed 15 Jan. 2017].

Simonetti 2009: Simonetti P. Translating a Book into Another Book? Graphic Novels Between Comics and Literature. - Proceedings of the $20^{\text {th }}$ AISNA Conference. Torino, 24-26 September 2009. 378-385.

Watt: Watt I. in Graphic Novel. The Chicago School of Media Theory. 1-7. <https://lucian. uchicago.edu/blogs/mediatheory/keywords/graphic-novel/> [Accessed 18 Jan. 2017]. 